\title{
ATR Gene
}

National Cancer Institute

\section{Source}

National Cancer Institute. ATR Gene. NCI Thesaurus. Code C20560.

This gene is involved in cell cycle checkpoints and DNA recombination. 